\title{
Transformation of inputs in a model of the rat hippocampal CA1 network
}

\author{
Andrey V Olypher ${ }^{1,2^{*}}$, William W Lytton ${ }^{2}$, Astrid A Prinz ${ }^{1}$ \\ From Nineteenth Annual Computational Neuroscience Meeting: CNS*2010 \\ San Antonio, TX, USA. 24-30 July 2010
}

The hippocampus is one of the brain structures critically implicated in schizophrenia. Known schizophrenia-specific alterations in the hippocampal neurons are subtle. Their impact on the information processing in the hippocampus is poorly understood. A core difficulty is the lack of understanding of normal hippocampal functioning. Here, we focus on some simple but potentially fundamental characteristics of that functioning, and assess them in a model of the CA1 hippocampal network.

In our study, network effects resulted from overlapping inputs to modeled CA1 principal cells; we did not consider explicit interactions between the cells. The overlap was determined on the basis of the known hippocampal anatomy [1]. We assumed that all the cells received their excitatory and inhibitory inputs synchronously, as if strongly modulated by ongoing theta and gamma rhythm [2]. Each cell was modeled by biophysically realistic multicompartment models of reconstructed CA1 principal cells using NEURON $[3,4]$.

Our analysis of the network performance was motivated by our earlier model of the hippocampal network under normal and psychotic conditions [5]. When "normal", that attractor model network was able to generalize similar input patterns and discriminate distinct ones. Such behavior required time sufficient for the network dynamics to converge to appropriate steady states. In the present study, we complement that approach by assessing similar abilities of generalizing and discriminating of inputs. However here we used much more realistic neuronal models and did not take into account associative properties of the network. We characterized the network performance by its response to synchronous inputs within 40 milliseconds. If a modeled CA1cell spiked within this interval it contributed "1" to the output of the network, otherwise the cell contributed " 0 ". In particular, we determined how the average distance

* Correspondence: andrei.olifer@emory.edu

1Biology Department, Emory University, Atlanta, GA 30033, USA between the output patterns depended on the average distance between the input patterns. We performed this analysis for CA3, entorhinal, and mixed input patterns.

\section{Author details}

${ }^{1}$ Biology Department, Emory University, Atlanta, GA 30033, USA.

2Department of Physiology and Pharmacology, SUNY, Downstate Medical Center, Brooklyn, NY 11203, USA.

Published: 20 July 2010

\section{References}

1. Amaral DG, Witter MP: The three-dimensional organization of the hippocampal formation: a review of anatomical data. Neuroscience 1989, 31:571-591.

2. Whittington MA, Traub RD, Jeffreys JGR: Synchronized oscillations in interneuron networks driven by metabotropic glutamate receptor activation. Nature 1995, 373:612-615.

3. Jarsky T, Roxin A, Kath WL, Spruston N: Conditional dendritic spike propagation following distal synaptic activation of hippocampal CA1 pyramidal neurons. Nat Neurosci 2005, 8:1667-1676.

4. Hines ML, Carnevale NT: The NEURON simulation environment. Neural Comput 1997, 9:1179-1209.

5. Olypher AV, Klement D, Fenton AA: Cognitive disorganization in hippocampus: a physiological model of the disorganization in psychosis. J Neurosci 2006, 26:158-168.

doi:10.1186/1471-2202-11-S1-P56

Cite this article as: Olypher et al:: Transformation of inputs in a model of the rat hippocampal CA1 network. BMC Neuroscience 2010 11(Suppl 1): P56.

Submit your next manuscript to BioMed Central and take full advantage of:

- Convenient online submission

- Thorough peer review

- No space constraints or color figure charges

- Immediate publication on acceptance

- Inclusion in PubMed, CAS, Scopus and Google Scholar

- Research which is freely available for redistribution 